\title{
AN ANALYSIS OF THE QUALITY AWARD MODEL BY AHP
}

\section{RAKESH K. VIDHATE ${ }^{1} \&$ SUNIL V. DESHMUKH ${ }^{2}$}

${ }^{I}$ Department of Mechanical Engineering, National Fire Service College, Maharashtra, India

${ }^{2}$ Professor, Department of Mechanical Engineering, Bapurao Deshmukh College of Engineering, Maharashtra, India

This paper is proposed as a model for ranking of fields, criteria and sub-criteria in the quality award model. It is based on the Analytic Hierarchy Process (AHP). The AHPis used to find the criteria's weightage and the sub criteria's priority, are applied to determine priorities and weightage, to recognize, apply and coordinate the factory resources. The results confirmed the efficient performance of the proposed model. The proposed model used an example problem and it provided a new tool for planning and analysing of excellence organizations more effectively.
\end{abstract}

KEYWORDS: AHP, Quality Award Model \& Pair-Wise Comparison

Received: Nov 13, 2018; Accepted: Dec 07, 2018; Published: Jan 07, 2019; Paper Id.: IJMPERDFEB201926

\section{INTRODUCTION}

Quality award are prizes or rewards granted to the organizations with the highest quality of performance in certain aspects of business by organizations specially established to appreciate the work of such organization.

The main goal of quality awards is to assess the performance of any applying company or individual against certain evaluation criteria. There are quality awards, which estimate the result of organizing work, which can be done by estimating consumer's satisfaction after using the product produced by a certain organization. The award aims to encourage the scientific, economic and social development of the country by diffusing successful management practices and techniques, and establishing benchmarks for the continuous improvement of organizations. The National Quality Award fosters improved management quality and increased organizational competitiveness. The award process seeks to:

- Encourage the cultural, political, scientific, technological, economic and social development

- Provide organizations with a benchmark model for their continuous improvement

- Publicly recognize the management quality excellence of World Class organizations

- Disseminate successful management practices aimed at benchmarking.

The design of National Quality Awards/Business Excellence Models is to promote quality awareness, understand the requirements for quality excellence and share information on successful strategies and their benefits. Typically NQAs/BEMs contain 6 to 10 criteria and a further twenty to thirty sub-criteria. The awards are made yearly to only the most deserving organization which score more against the weightage allotted to the given evaluation criteria. They are a nation's highest prize for achievement in the best quality management practices. The awards are instituted by government, private bodies with the participation of judges and examiners from both 
public and private business organizations.

The Weightage/Points allocated to the major NQAs/BEMs across the globe are depicted below in table 1

Table 1

\begin{tabular}{|c|c|c|}
\hline NQA/BEM & Criteria & Points \\
\hline \multirow{9}{*}{ DEMING } & A. Basic Categories & 100 \\
\hline & Management policies and their deployment & 20 \\
\hline & New product development, Work process innovation & 20 \\
\hline & Maintenance and improvement & 20 \\
\hline & Management system & 10 \\
\hline & Information analysis and utilization of IT & 15 \\
\hline & Human resources development & 15 \\
\hline & B. Unique Categories & 100 \\
\hline & C. Role of Top Management & 100 \\
\hline \multirow{9}{*}{ EFQM } & Leadership & 100 \\
\hline & Strategy & 100 \\
\hline & People & 100 \\
\hline & Partnership and Resources & 100 \\
\hline & Processes, Products and Services & 100 \\
\hline & Customer Results & 150 \\
\hline & People Results & 100 \\
\hline & Society Results & 100 \\
\hline & Key Results & 150 \\
\hline \multirow{7}{*}{ MBNQA } & Leadership & 120 \\
\hline & Strategic Planning & 85 \\
\hline & Customer and Market Focus & 85 \\
\hline & Measurement, Analysis and Knowledge Management & 90 \\
\hline & Workforce Focus & 85 \\
\hline & Process Management & 85 \\
\hline & Results & 450 \\
\hline \multirow{7}{*}{ ABEA } & Leadership & 150 \\
\hline & Strategy and Planning & 95 \\
\hline & Information and Knowledge & 95 \\
\hline & People & 100 \\
\hline & Customers and other Stakeholders & 150 \\
\hline & Process Management, Improvement and Innovation & 110 \\
\hline & Results & 300 \\
\hline \multirow{11}{*}{ SAEA } & Leadership & 100 \\
\hline & Policy and Strategy & 70 \\
\hline & Customer and Market Focus & 60 \\
\hline & People Management & 90 \\
\hline & Resources and Information Management & 60 \\
\hline & Processes & 120 \\
\hline & Impact on Society & 60 \\
\hline & Customer Satisfaction & 170 \\
\hline & People Satisfaction & 90 \\
\hline & Supplier and Partnership Performance & 30 \\
\hline & Business Results & 150 \\
\hline \multirow{7}{*}{ RGNQA } & Leadership & 100 \\
\hline & Policies, objectives and strategies & 100 \\
\hline & Human resource management & 50 \\
\hline & Resources & 100 \\
\hline & Processes` & 150 \\
\hline & Customer focused results & 200 \\
\hline & Employee Satisfaction & 50 \\
\hline
\end{tabular}




\begin{tabular}{|c|c|c|}
\hline & Impact on environment and society & 100 \\
\hline & Business Results & 150 \\
\hline \multirow{9}{*}{ GPNQA } & Organizational Leadership & 120 \\
\hline & Strategic Planning & 100 \\
\hline & Information Management & 80 \\
\hline & Human Resource Management & 100 \\
\hline & Process Management & 120 \\
\hline & Employee Satisfaction & 80 \\
\hline & Customer Satisfaction & 150 \\
\hline & Impact on Society & 150 \\
\hline & Business Results & 100 \\
\hline \multirow{7}{*}{ IMC RBNQA } & Leadership & 120 \\
\hline & Strategic Planning & 85 \\
\hline & Customer Focus & 85 \\
\hline & Measurement, Analysis and Knowledge Management & 90 \\
\hline & Workforce Focus & 85 \\
\hline & Operations Focus & 85 \\
\hline & Results & 450 \\
\hline \multirow{9}{*}{ CII EXIM } & Leadership & 100 \\
\hline & Strategy & 100 \\
\hline & People & 100 \\
\hline & Partnership and Resources & 100 \\
\hline & Processes, Products and Services & 100 \\
\hline & Customer Results & 150 \\
\hline & People Results & 100 \\
\hline & Society Results & 100 \\
\hline & Key Results & 150 \\
\hline
\end{tabular}

Source: Union of Japanese Scientist \& Engineers (2012), European Foundation for Quality Management (2010), MBNQA criteria for performance excellence (2008), Sai Global (2012), National Chamber of Commerce (2012), Exploring a Causal Model for the Brazilian National Quality Award (2010), SAEM (2008), Rajiv Gandhi National Quality Award (2010), Golden Peacock National Quality Award (2010), IMC Ramkrishna Bajaj National Quality Award (2012), CII EXIM Bank Award for Business Excellence (2012).

\section{LITERATURE REVIEW}

Table 2 shows some researches using AHP and integrating it with other decision making methods in quality award model.

Table 2

\begin{tabular}{|c|l|l|}
\hline Year & \multicolumn{1}{|c|}{ Authors } & \multicolumn{1}{c|}{ Methodology and Results } \\
\hline 2018 & $\begin{array}{l}\text { The authors propose to use seven different fuzzy scales to evaluate firms using the } \\
\text { and Cengiz } \\
\text { Kahraman }\end{array}$ & $\begin{array}{l}\text { MBNQ criteria. Analytic Hierarchy Process (AHP) based fuzzy multi-criteria } \\
\text { decision-making approach was used to measure the performance excellence of } \\
\text { firms applying for MBNQA. The study proposes an integrating approach for the } \\
\text { testing business performance of MBNQA with the proposed AHP. The proposed } \\
\text { approach creatively proposes a new fuzzy AHP framework for MBNQA. This } \\
\text { study also proves the applicability of the proposed model by a numerical example. } \\
\text { Firstly, the four level hierarchy, comprising } 7 \text { criteria and eighteen sub-criteria of }\end{array}$ \\
\hline
\end{tabular}




\begin{tabular}{|c|c|c|}
\hline & & $\begin{array}{l}\text { MBNQA were established. Each expert used } 7 \text { different triangular fuzzy scales for } \\
\text { establishing comparison matrices. The final weights of the firms were calculated } \\
\text { and ranked using the integral value method. Firm A was selected the most proper } \\
\text { firm for MBNQA than Firm B and C. The fuzzy MBNQA process has been } \\
\text { compared with Buckley's fuzzy approach. The results justify that the proposed } \\
\text { method produces meaningful outcomes. The proposed method is based on simple } \\
\text { arithmetic operations and it require less time when compared with Buckley's } \\
\text { approach. Both methodologies produced the same results in the application. }\end{array}$ \\
\hline 2016 & $\begin{array}{l}\text { Nitin Upadhye } \\
\text { and Durgesh } \\
\text { Sharma }\end{array}$ & $\begin{array}{l}\text { This paper proposes the use of AHP as powerful tools for evaluating the } \\
\text { manufacturing industry competitiveness in delivering the right quality in the right } \\
\text { quantity at the right time to its customer in the supply chain. The score of } \\
\text { different suppliers of the crankshaft can calculate by multiplying the global } \\
\text { priority weights and rating based on a five point scale of Outstanding, Good, } \\
\text { Average, Fair and Poor: and subsequently adding the resulting values. Industry } \\
\text { M/s XYZ has scored the highest weight of } 0.225 \text { points based on global priority } \\
\text { weights of three suppliers of a crankshaft. The results illustrate that the supplier } \\
\text { M/s XYZ has been on a right path to achieve leanness even it will a long journey } \\
\text { for the company. }\end{array}$ \\
\hline 2014 & $\begin{array}{l}\text { Manish Kumar } \\
\text { Sagar and Amit } \\
\text { Singh Tomar }\end{array}$ & $\begin{array}{l}\text { The authors review the concepts of the multiple criteria decision analysis and } \\
\text { demonstrate the AHP application for the quality improvement. Out of } 72 \text { factors } \\
\text { customer satisfaction scored first rank, top management commitment scored the } \\
\text { second rank and communication third place. By the use of AHP all the } 72 \text { factors } \\
\text { influence the TQM more and organizations have to consider these factors if they } \\
\text { are planning to implement TQM. }\end{array}$ \\
\hline 2014 & $\begin{array}{l}\text { Raghwendra } \\
\text { Banchhor and S. } \\
\text { K. Ganguly }\end{array}$ & $\begin{array}{l}\text { The authors analyzed a strategy to prioritize the qualitative factors which are } \\
\text { responsible for random occurrence of metal penetration in an automatic flaskless } \\
\text { molding casting process using Analytic Hierarchy Process (AHP). An AHP } \\
\text { structure is formed with criteria severity, occurrence and detection. The } \\
\text { alternatives are four areas of the foundry i.e. molding sand, operator, mold and } \\
\text { environment. } 16 \text { causes for metal penetration are placed as a sub-alternatives. On } \\
\text { the basis of the final weight of various sub-alternatives ranking is obtained for the } \\
\text { causes of metal penetration and three main causes are localized poor compactions, } \\
\text { wet lump in molding sand and blocked vents. After AHP analysis the critical } \\
\text { causes of metal penetration were found to reduce the probability of occurrence of } \\
\text { the defect. }\end{array}$ \\
\hline 2013 & $\begin{array}{l}\text { Alireza Yazdani } \\
\text { et. al. }\end{array}$ & $\begin{array}{l}\text { This paper evaluates critical success factors (CSFs) based on Malcolm Baldrige } \\
\text { National Quality Awards (MBNQA) and prioritize CSFs from different level }\end{array}$ \\
\hline
\end{tabular}




\begin{tabular}{|c|c|c|}
\hline & & $\begin{array}{l}\text { management's perspective on Iran. Extensive review of literature has been carried } \\
\text { out and includes Malcolm Baldrige National Quality Awards (MBNQA) as TQM } \\
\text { frameworks for the purpose of evaluating TQM CSFs and a questionnaire was } \\
\text { made to prioritize CSFs and the weight of each factor. Analytic Hierarchy Process } \\
\text { (AHP) method by Expert choice software was used for evaluating the factors. The } \\
\text { overall result is that Pars oil and gas company quality management experts treat } \\
\text { the inputs (leadership, strategic planning and customer focus with the score } 56,46 \\
\text { and } 35 \text { respectively) as much important as the outputs (results) with } 228 \text { value } \\
\text { points suggested by MBNQA. The practitioners of the POGC need to focus more } \\
\text { on leading criteria or inputs rather than the lagging criteria (results). The Malcolm } \\
\text { Baldrige model includes many features to evaluate the performance of business } \\
\text { organizations. Malcolm Baldrige can be used as a comprehensive model to } \\
\text { evaluate the performance of business organizations. With the use of this model, } \\
\text { the organization's weakness and strengths would be clear to the authorities, and } \\
\text { they can take steps towards the improvement and the growing promotion of their } \\
\text { organization by using these data. }\end{array}$ \\
\hline 2013 & $\begin{array}{l}\text { Elahe } \\
\text { Shariatmadari } \\
\text { Serkani et. al. }\end{array}$ & $\begin{array}{l}\text { This paper presents the results of the application of AHP and ANP to select a } \\
\text { project within the field of healthcare in Iran. The opinions of } 15 \text { experts are } \\
\text { collected by means of a matrix based questionnaire. Analytic Hierarchy Process } \\
\text { (AHP) method by Expert choice software was used for the development of the } \\
\text { model and Analytic Network Process (ANP) method was applied to rank the ten } \\
\text { improvement projects with the help of the super decisions software. The analysis } \\
\text { of selecting improvement projects was carried out by comparison of two methods, } \\
\text { AHP and ANP. Calculating the super-matrix and limit matrix shows that the } \\
\text { priorities in ANP technique are different with AHP. Both decision matrices ANP } \\
\text { and AHP, for the ten improvement project alternatives evaluated. ANP method } \\
\text { resulted more suitable than the AHP method because it enhances the function of } \\
\text { the AHP to develop a complete model that can incorporate interdependent } \\
\text { relationships between elements from different levels or within levels, which are } \\
\text { assumed to be uncorrelated in AHP. }\end{array}$ \\
\hline 2012 & $\begin{array}{l}\text { Paulo Sampaio } \\
\text { et.al }\end{array}$ & $\begin{array}{l}\text { This paper present the comparative analysis of the contents and structures of the } \\
\text { most commonly used business excellence models, as well as describes data } \\
\text { related with their usage was analyzed by SPSS } 18.0 \text { software and it comes up with } \\
\text { a recommendation in the direction of possible convergence in the future into a } \\
\text { single consensual excellence model (World Quality Award), to be developed and } \\
\text { applied all over the world, since all models do share a common set of values, } \\
\text { principles and criteria. }\end{array}$ \\
\hline
\end{tabular}




\begin{tabular}{|c|c|c|}
\hline 2011 & $\begin{array}{l}\text { Amir Karbassi } \\
\text { Yazdi and } \\
\text { Hossein } \\
\text { Karbassi Yazdi }\end{array}$ & $\begin{array}{l}\text { This paper proposes a customized EFQM excellence model for IRANA by } \\
\text { combining and integrating the EFQM model and AHP to assess and measure the } \\
\text { company's performance. The best and worst results were obtained in Leadership } \\
\text { and Society Results, respectively. Using this approach, the organization will be } \\
\text { able to balance its priorities to allocate resources and to generate more realistic } \\
\text { business plans. }\end{array}$ \\
\hline 2007 & $\begin{array}{l}\text { Anil K. Sharma } \\
\text { and Balvir } \\
\text { Talwar }\end{array}$ & $\begin{array}{l}\text { This paper evolves the Universal Business Excellence Model (UBEM) with the } \\
\text { integration of the common features of business excellence models (BEMs), a } \\
\text { questionnaire survey was used and the factor analysis of the variables (questions), } \\
\text { having maximum mean and minimum SD was undertaken. In the analysis KMO } \\
\text { and Bartlett Test, screen plot and rotated component matrix was used. To prove } \\
\text { the result the alpha value of the variables was also calculated in the reliability test. } \\
\text { The Levene's test for equality of variances and t-test for equality of means was } \\
\text { applied on the segmented groups. Further, one way ANOVA analysis was done } \\
\text { between various age groups as well as experience profile. }\end{array}$ \\
\hline 2001 & $\begin{array}{l}\text { Jacob K. } \\
\text { Eskildsen et.al }\end{array}$ & $\begin{array}{l}\text { The researcher test whether or not the EFQM excellence model weightage } \\
\text { structure corresponds to the areas that Danish companies perceive. The } \\
\text { questionnaire consists of } 51 \text { items with } 45 \text { statements covering the EFQM } \\
\text { excellence model (five for each criterion) and six questions covering } \\
\text { demographics. The data from this survey have been analysed through factor score } \\
\text { regression on confirmatory factor analysis of } 5000 \text { bootstrapped samples. The } \\
\text { analysis shows that Danish companies are not at all in alignment with the EFQM } \\
\text { weights. They would allocate approximately } 700 \text { points to the enabler criteria and } \\
300 \text { points to the result criteria. This may be because Danish companies have } \\
\text { realized that focusing on the enabler criteria creates excellent results. Companies } \\
\text { with } 50 \text { or more employees put a higher emphasis on "policy and strategy" (202 } \\
\text { points) than on "partnerships and resources" ( } 114 \text { points). The criteria "customer } \\
\text { results" and "people results" are perceived as more important than "society } \\
\text { results" and "key performance results". }\end{array}$ \\
\hline 2001 & $\begin{array}{l}\text { P.A.Cauchick } \\
\text { Miguel }\end{array}$ & $\begin{array}{l}\text { The paper presents the case study of Brazilian National Quality Award and } \\
\text { compares it with the five major internationally recognized quality awards from } \\
\text { USA, Europe, Canada, Australia and Deming Prize of Japan, in which both the } \\
\text { final score and the report of strengths and opportunities for improvement for } \\
\text { National Quality Award of Brazil is carried out with the help of a software called } \\
\text { Sideral, specially designed by a company to conduct the award process. }\end{array}$ \\
\hline
\end{tabular}




\section{EVALUATION CRITERIA}

The present work proposed the quality award model based on six evaluation criteria and 18 sub-criteria as shown in table 3 for implementation of AHP technique namely:

- Leadership- The leadership criteria examine how the organizations Senior Leaders guide and sustain the organization.

- Strategy- Organizations implement their mission and vision by developing stakeholder focused strategy.

- Customer- Describe how the organization determines requirement, expectations and preferences of customers and markets to ensure the continuing relevance of products and services.

- Partnership and Supplier Management- Organizations plan and manage external partnerships, suppliers and internal resources in order to support strategy and policies and the effective operation of processes.

- Process Management- Describes how the organization designs, manages and improves its processes in order to support its policy and strategy.

- Result- Examines the organization's performance and improvement in all key areas.

Table 3: Model Criteria and Sub-Criteria

\begin{tabular}{|c|l|l|}
\hline Sr. No & \multicolumn{1}{|c|}{ Criteria } & \multicolumn{1}{c|}{ Sub-criteria } \\
\hline 1 & Leadership & $\begin{array}{l}\text { a)Roles and Commitment } \\
\text { b)Social Responsibilities } \\
\text { c)Quality Culture }\end{array}$ \\
\hline 2 & Strategy & $\begin{array}{l}\text { a)Strategy Development } \\
\text { b)Innovation and Growth } \\
\text { c)Strategy Deployment }\end{array}$ \\
\hline 3 & Customer & $\begin{array}{l}\text { a)Market Knowledge } \\
\text { b)Supplier Relationship Management } \\
\text { c)Customer Communication and Relationship Management }\end{array}$ \\
\hline 4 & $\begin{array}{l}\text { Partnership and } \\
\text { Supplier Management }\end{array}$ & $\begin{array}{l}\text { a)Partners and Supplier Relationship Management } \\
\text { b)Performance and Quality } \\
\text { c)Supplier Involvement }\end{array}$ \\
\hline 5 & Process Management & $\begin{array}{l}\text { a)Quality Management System } \\
\text { b)Controlled Implementation } \\
\text { c)Process Quality Assessment and Improvement }\end{array}$ \\
\hline 6 & Result & $\begin{array}{l}\text { a)Customer Results } \\
\text { b)People Results } \\
\text { c)Society Results }\end{array}$ \\
\hline
\end{tabular}

\section{METHODOLOGY}

AHP is a popular and useful method for ranking items and calculating weights on which research are carried out on large. The Analytic hierarchy Process (AHP), designed and developed by Saaty (1980) is widely used multiple criteria decision making method and generally applies to the decisions to be made on multiple criteria under an uncertainty condition. Apart from other facts, this is rooted in the special structure of the AHP, which follows the intuitive way in which managers solve problems, and in its easy handling compared with other multi criteria decision-making procedures. Hence the intuitively solved decision problems can now be solved as procedure-orientated using AHP. The use of AHP leads to both, more transparency of the quality of management decisions and an increase in the importance of AHP 
(Ossadnik W\& Lange O, 1999).

AHP has proven to be a popular technique for determining weights in multi criteria problems. AHP process is having three steps which are identified and organizing goal, criteria and sub-criteria into a hierarchy; evaluating par wise comparisons between the relevant elements at each level of the hierarchy and synthesis uses the solution algorithm of the results of the pair wise comparison over all levels.

The following five steps AHP procedure is used for analyzing the problem.

- Construct a set of pair wise comparison matrices for criteria's and each for the sub-criteria's by using the scale shown in table 4.

- Calculating the priority vector for criterion.

- $\quad$ Calculating $\lambda \max$, consistency index (CI) and consistency index (CI).

- $\quad$ Selecting an appropriate value of the random consistency ratio (RI) from table-5.

- $\quad$ Checking the consistency of the pair wise comparison matrix from CI.

Table 4: AHP Scale of Importance for Pair-Wise Comparison

\begin{tabular}{|c|l|}
\hline Rating & \multicolumn{1}{c|}{ Degree of Importance } \\
\hline 1 & Equal Importance \\
\hline 3 & Moderate Importance \\
\hline 5 & Strong or Essential Importance \\
\hline 7 & Very strong Importance \\
\hline 9 & Extreme Importance \\
\hline $2,4,6,8$ & Intermediate Importance \\
\hline
\end{tabular}

Table 5: Random Consistency (RI)

\begin{tabular}{|l|c|c|c|c|c|c|c|c|c|c|}
\hline Matrix size & 1 & 2 & 3 & 4 & 5 & 6 & 7 & 8 & 9 & 10 \\
\hline R.I & 0 & 0 & 0.58 & 0.9 & 1.12 & 1.24 & 1.32 & 1.41 & 1.45 & 1.49 \\
\hline
\end{tabular}

For ranking the sub-criteria and to know the global priority of each sub-criterion, combining the criteria priorities and the priorities of each criteria relative to each criterion to develop an overall priority ranking of the sub-criteria. The ranking of criteria's and sub-criteria are shown in table 6 and 7 respectively. This global priority helps to rank all the sub-criteria starting from the most focused to least focused with respect to the quality award.

Table 6: Rank of Criteria's

\begin{tabular}{|l|c|c|}
\hline \multicolumn{1}{|c|}{ Criteria } & Priority & Rank \\
\hline Leadership & 0.418 & 1 \\
\hline Strategy & 0.191 & 2 \\
\hline Customer & 0.190 & 3 \\
\hline Process Management & 0.091 & 4 \\
\hline Result & 0.073 & 5 \\
\hline Partnership and Supplier Management & 0.037 & 6 \\
\hline
\end{tabular}

Table 7: Rank of Sub-Criteria's

\begin{tabular}{|l|l|l|l|}
\hline \multicolumn{1}{|c|}{ Sub-Criteria } & Local Priority & \multicolumn{1}{c|}{ Global Priority } & Rank \\
\hline Roles and Commitment & 0.633 & 0.264 & 1 \\
\hline Strategy Development & 0.633 & 0.121 & 2 \\
\hline Quality Culture & 0.261 & 0.108 & 3 \\
\hline
\end{tabular}




\begin{tabular}{|l|l|l|l|}
\hline \multicolumn{4}{|c|}{ Table 7: Contd., } \\
\hline $\begin{array}{l}\text { Customer Communication and } \\
\text { Relationship Management }\end{array}$ & 0.548 & 0.105 & 4 \\
\hline Quality Management System & 0.633 & 0.057 & 5 \\
\hline Innovation and Growth & 0.261 & 0.049 & 6 \\
\hline Social Responsibilities & 0.106 & 0.046 & 7 \\
\hline Customer Results & 0.643 & 0.046 & 8 \\
\hline $\begin{array}{l}\text { Supplier Relationship } \\
\text { Management }\end{array}$ & 0.241 & 0.045 & 9 \\
\hline Market Knowledge Assessment & 0.211 & 0.040 & 10 \\
\hline $\begin{array}{l}\text { Process Quality } \\
\text { and Improvement }\end{array}$ & 0.261 & 0.024 & 11 \\
\hline Performance and Quality & 0.643 & 0.023 & 12 \\
\hline Strategy Deployment & 0.106 & 0.021 & 13 \\
\hline People Results and Supplier & 0.282 & 0.021 & 14 \\
\hline $\begin{array}{l}\text { Partners and } \\
\text { Relationship Management }\end{array}$ & 0.282 & 0.011 & 15 \\
\hline Controlled Implementation & 0.106 & 0.010 & 16 \\
\hline Society Results & 0.075 & 0.006 & 17 \\
\hline Supplier Involvement & 0.075 & 0.003 & 18 \\
\hline
\end{tabular}

\section{CONCLUSIONS}

Quality award is the most advantageous tool for the improvement of the status in the market and also for the promotion of products. This paper present AHP as a decision making tool against the multiple criteria (6) and sub-criteria (18). The various sub-criteria which are crucial for small scale industry are identified and analyzed systematically using Analytic Hierarchy Process (AHP). The tool has been used by different researchers in various fields for selecting among alternatives. Application of this technique helps in analysis of various criteria and sub-criteria leading to selection, comparison and ranking of organization based on performance.

In this study roles and commitment have got the highest global priority. It is because the roles and commitment of leadership criteria must set the direction and define and follow up the goals by creating opportunities for the employees to achieve the same. Thus, fororganizational growth and development top management initiation, direction and guidance must require. Commitment of top managers creates an environment of continuous improvement through the proper leadership and by establishing quality policies, providing training and resource to employees and participating in quality improvement procedure. Strategy development scored the second rank which places a vital role for the growth and development of an organization. It refers to the organizational approach to preparing for the future. It might utilize various types of forecasts, projections, options or other approaches to envisioning the future for purposes of decision making and resource allocation. Organizational strategy in relation to the changes in services, products and product lines are the key factors for the growth of the organization in the competitive market.

In future the weightages may vary depending upon type of organization under consideration, size of organization and geographical location. 


\section{REFERENCES}

1. Alireza Yazdani et.al. (2013). Evaluation of Critical Success Factors in Total Quality Management Implementation and Prioritization with AHP-Case Study: Pars Oil and Gas Company, European Online journal of Natural and Social Sciences, (pp.1624-1633).

2. Amir Karbassi Yazdi and Hossein Karbassi Yazdi. (2011). Using Analytic Hierarchy Process and Multi Dimensional Decision Making methods for Analyzing the Excellence Organization, Australian Journal of Basic and Applied Sciences, (pp.1972-1980).

3. Anil K Sharma and Balvir Talwar.(2007).Evolution of Universal Business Excellence Model incorporating Vedic philosophy,Measuring Business Excellence, (pp. 4-20).

4. Elahe Shariatmadari Serkani et.al. (2013).Using AHP and ANP approaches for selecting improvement projects of Iranian Excellence Model in healthcare sector,African Journal of Business Management, (pp.2271-2283).

5. Jacob K Eskildsen et.al. (2001).The criterion weights of the EFQM excellence model,International Journal of Quality \& Reliability Management, (pp. 783-95).

6. Kumar, R. S. Latent Heat Storage Material Evaluation Base On Ahp And Topsis For Low Temperature Solar Heating Applications.

7. Manish Kumar Sagar and Amit Singh Tomar.(2014).Ranking Critical Success Factors of Total Quality Management by AHP, International Journal of Mechanical and Production Engineering, (pp.29-34).

8. Nitin Upadhye and Durgesh Sharma.(2016).Analytical Hierarchical Process to Assess the Lean Status of Suppliers, University of Modern Sciences, (pp.86-96).

9. P.A Cauchick Miguel. (2001).Comparing the Brazilian national quality award with some of the major prizes", The TQM Magazine, (pp. 260-272).

10. Raghwendra Banchhor and S. K. Ganguly.(2014).Metal Penetration and its Resolution: Ranking of Qualitative Factors in Automatic Flaskless Green Sand Casting Process Using Analytic Hierarchical Process, International Journal of Innovative Trends in Engineering, (pp.1-6).

11. Serhat Aydin and Cengiz Kahraman.(2018).Evaluation of firms applying to Malcolm Baldrige National Quality Award: a modified fuzzy AHP method, Complex and Intelligent Systems, (pp.1-11).

12. T. L. Satty.(1980).The Analytic Hierarchy Process. McGraw-Hill. 